\title{
Efficacy of Chinese Herbal Formulation Combined With Bone Mesenchymal Stem Cells in Repairing Rat Cartilage Tissues
}

Research article

Keywords:

Posted Date: January 12th, 2021

DOl: https://doi.org/10.21203/rs.3.rs-93186/v2

License: (c) (i) This work is licensed under a Creative Commons Attribution 4.0 International License.

Read Full License 


\section{Abstract}

The authors have requested that this preprint be withdrawn due to erroneous posting.

\section{Full Text}

The authors have withdrawn this preprint from Research Square. 